\title{
Traditional Rice Farming Ritual Practices Of The Banjar Tribe Farmers in South Kalimantan
}

\author{
Karunia Puji Hastuti \\ Student of Doctoral Program, Department of Geography \\ Education, Universitas Negeri Malang \\ Malang, Indonesia \\ karunia_pujihastuti@yahoo.com
}

\author{
Sumarmi, Dwiyono Hari Utomo, Budijanto \\ Faculty of Social Science \\ Universitas Negeri Malang \\ Malang, Indonesia
}

\begin{abstract}
The majority of Banjar tribe communities work as farmers and convert to Islam. Banjar tribal society called the rice farming system in terms bahuma. Ritual activities in bahuma intended to ask to God in order to harvest abundant and avoided from crop failures. This study aims to describe ritual performed in the Banjar tribe farmers bahuma activities. The method used in this research is descriptive qualitative. Data collection was done by observation, interview, documentation and literature study. Data were analyzed using Miles and Huberman interactive model. The research findings indicate that farmers Banjarese perform rituals during the process: manaradak (seeding rice), batanam (planting rice in paddy), mangatam (harvest), and imbah katam (after the harvest).
\end{abstract}

Keywords - ritual, bahuma, Banjar tribe

\section{INTRODUCTION}

Banjarese farming systems in South Kalimantan [1] referred to as system urang banjar (Banjarese System). In addition to the term system urang banjar/ banjarese system, Banjar tribe farmers also familiar with the term bahuma for farming activities. Bahuma even more familiar term among the Banjar tribe. Bahuma activities (farming) conducted by Banjar tribe farmers generally still managed traditionally, ranging from seed rice seedlings, planting, harvesting, postharvest up. Bahuma activity has been hailed by the Banjar tribe for generations, they form a system of traditional knowledge through experience and experiments, it is a process that is adaptive to the surrounding environment. Adaptability makes activities bahuma able to survive until now.

As with other tribes in Indonesia which has a variety of unique rituals, Banjar tribe in South Kalimantan also has a unique ritual, especially in bahuma activities. According [2], the ritual always identified with the habit (habit) or routines. Furthermore Rothenbuhler explained that, "The ritual is the voluntary performance of appropriately patterned behavior to symbolically effect Participate in the serious or life". Meanwhile, [3] to understand the ritual as a habitual action (action hereditary), formal action and also contain transcendental values. The same thing is also explained Sitomorang [4] is meant a ritual is related to spiritual beliefs and beliefs with a certain purpose. Rituals are often understood as a system of cultural construction of symbolic communication. Rituals are often practiced through verbal and non verbal as well as actions expressed in various media. Grimes [5] proposes models of rituals: ceremony, liturgy, magic and celebration.

Traditional rituals are social activities that involve the community in working together to achieve common safety goals. This is in line with the opinion [6] traditional ritual is one form of realization of a form of culture in the form of a pattern of patterned behavior activities of humans in the community or often called the social system. Furthermore [7] describes "rituals that are basic to the social act of humanity". This social system consists of human activities that interact from time to time and always follow certain patterns based on customary behavior [8]. In essence, the traditional ritual contains not only human activities that are symbolically oriented with nature and supernatural powers, but behind that every ceremony is the embodiment of ideas and aspirations (the will). The idea and the will contain knowledge, values, beliefs, rules that relate human relationships to others, human relationships with their natural environment, and to the supernatural world [9].

Observing these views, it is understood that rituals are associated with voluntary performances with communityorganized patterns of patterned behavior (based on custom). Ritual is one way to communicate. Realizing that the ritual as one way in communicating, then the term ritual communication emerged. The term of ritual communication was first proposed [10]. He mentioned that, "In a ritual definition, communication is linked to terms such as" sharing "," participation "," association "," fellowship ", and" the possession of a common faith ". Furthermore, [10] added in the ritual view, communication is not directly directed to disseminate the message in a space, but rather the maintenance of a community at a time. Communication patterns built in view of the ritual is sacred ceremony (ceremonial sacred/holy) where everyone together and assembled (fellowship and commonality). In line with [3] explains the pattern of communication in ritual perspective is not that the sender sends a message to the recipient, but as a sacred ceremony in which everyone shares a common part in fellowship and assembly as well as performing the banquet. In the view of ritual, the more important is the community togetherness in 
doing prayer and ceremonial. Furthermore, [11] describes communication with the unseen world can not be implemented by means of communication in the form of everyday language but with symbols that serve as a medium of communication believed to have magical or magical values with the aim can be established communication that can be interconnected.

Banjar tribe community life generally believe the presence of the fine (supernatural beings), both evil and good. Similarly, people in the village of Dalam Pagar (Kabupaten Banjar), they believe in the existence of the occult life. Therefore, they often hold rituals associated with various aspects of life of which are conducted in the bahuma. Ritual activities undertaken bahuma Banjar tribe farmers steeped in the nuances of Islamic, in view of the majority of farmers Banjar tribe embraced Islam. This can be seen from the use of readings taken from the Qur'an. Ritual performed Banjar tribe farmers in activities ranging from manaradak (seed), batanam (growing rice), mangatam (harvest), and imbah katam (after the harvest).

\section{METHOD}

The method used in this research is descriptive qualitative, where the result of this research try to explain in detail the situation in the field. In research, theories and data sources can develop in the field. The location of this research is in Dalam Pagar village (Kabupaten Banjar). Farmers Banjarese generally being subjects in this study. Key informants in this research is the traditional leaders/community and kapala padang. Objects that were observed in this study is the ritual of tribal farmers of Banjar bahuma activities ranging from manaradak activities (seed), batanam (growing rice), mangatam (harvest), and imbah katam (after the harvest). The data collection is done by observation, interviews, documentation and review of relevant literature on the agricultural system Banjar tribe. The observation technique is a structured observation in which the researcher has prepared the observation guideline. Documentation methods are used to supplement data and other information obtained from relevant agencies or other reference sources. The process of face to face interviews were conducted in person (face to face) with key informants. Interview guidelines used as an instrument to facilitate the interviews with sources or key informants. The validity of the data used in this research is to use triangulation techniques. Data analysis techniques performed by data reduction, data presentation, and withdrawal of conclusions / verification [12].

\section{RESULT}

The life of the Banjar people in Desa Dalam Pagar (Kabupaten Banjar) is colored by religious life based on Islamic teachings. In fact almost can be said, the whole life of society is based on religious sentiments derived from the teachings of Islam. The majority of Banjar tribe people in Desa Dalam Pagar work as traditional rice farmers. Agricultural systems by farmers Banjar tribe consists of four main activities, namely: manaradak (seed), batanam (growing rice), mangatam (harvest), and imbah katam (after the harvest). Here ritual at every activity bahuma Banjar tribe farmers in South Kalimantan.

\section{Manaradak (Seed)}

Banjar tribe farmers have several terms for the activities of sowing rice. The first term is mamalai grain is sprinkled over the muddy ground, which deliberately prepared and covered with straw. The second term is manaradak which include grain into the drill hole/crab (hole where planting rice). The next term is maampak/malacak to plant while grain rice that grow into saplings, and then after some time the child was lifted for planting rice back in the actual fields (fields).

Usually before the ritual performed in pahumaan (rice fields), at the evening shalat hajat performed in congregation lavatory. Shalat hajat is held after shalat magrib, followed by reading Shalawat and surah Yasin. The purpose of shalat hajat is to ask Allah SWT so that bahuma activities bring blessings and avoid harvest failure. Previous rice seedlings will be planted placed near paimaman (the imam). It is time for shalat isya' to be continued with the prayer in congregation. Finished the prayer ritual performed salamatan to serve food brought by members of the public who would bahuma (farming).

After completion of the ritual salamatan, paddy seed given to someone who had the honor to manaradak, then taken home and stored for one night at his home. The rice seeds should be brought to the venue in pahumaan (rice field) the next day.

Based on the information society Banjar tribe who lived in Dalam Pagar village (Banjar District) that the grains of rice to be sown, dirabun beforehand that grain smoked over a fire parapen (incense) while saying kur sumangat many times. The word kur sumangat may connote a blessing. Once smoked, grains of rice and then put into the water, when entering the rice into the water was read surah Al-Fatihah (one time) and Shalawat (three times), the term Banjar tribe farmers in this activity is mamalai. In addition there is also a term mamalai/manaradak which includes grain into the tugal hole/umang. Based on information from informants, when inserting grains of rice into the tugal hole/umang recited tasbih (Subhanallah, Alhamdulillah, Allahu Akbar). The reason given why it should be recited tasbih for paddy supposedly came from plants in heaven brought to earth to become human food that humans should be thankful to God for what has been given. For the purposes of bamula manaradak (beginning seed) is usually held also salamatan to prepare porridge made from rice flour called kokoleh and recited prayers survived. Presentation of kokoleh porridge always been associated by the public with the term Banjar tribe is bapakoleh (get results).

\section{A. Batanam (Planting Rice in Rice)}

For the purposes of bamula batanam (begin planting rice in paddy), family farmers usually prepare porridge kokoleh be eaten together in dangau (hut that was in the fields) after the ritual is complete. For bamula batanam takes three/seven tugal hole/umang whose position was made in the middle of rice fields. When will plant tugal hole/umang first, first recited Syahadat and read Ayat Kursi (Ayat Allahula), then the rice 
seed is inserted into a pit. Another informant said that he read Syahadat, Fatiha Four (consisting of surah Al-Fatihah, AlIkhlas, An-Nas, and Al-Falaq) and tasbih before entering the rice seed. Here there is the term bamamang (spell), the purpose of bamamang is removing the rice spirit to sail away and returned with a plentiful harvest.

When finished with the first hole, then move on to the second hole in the same way and reading, and so on until the last. Farmers who perform rituals bamula, usually do it alone without the help of others. Enough for him to prepare kokoleh porridge and read Bismillah and Fatiha Four when planting hole first, and read Bismillah when planted next hole (through hole to seven). Kokoleh porridge was served immediately after completion bamula, and the farmers who happened to be in the fields adjacent invited to participate and enjoy. Then the cultivation of rice fields continued until finished.

When finished planting rice in the fields, farmers in Dalam Pagar Village (Banjar District) usually surrounds the field while burning parapen (incense) and whispered mamangan / mantra's to Rice: " wahai Nur hayatullah batanang-tanang haja di parjalanan imbah tuntung bajalan kami siap haja manunggui ikam bulik wan kami siapakan kasinggahan ikam lawan tujuh buting gadung ". Meaning: O Nur Hayatullah (name of paddy) to be calm in his duty of sailing and that the farmer was ready to wait with seven holes to receive his return (rice).

Still in Banjar District, precisely in the Gambut District also has a tradition of collective salamatan and implemented Langgar (Mosque) before the sowing activity. For farmers rich, usually held salamatan tuntung batanam (salvation finished planting rice) in her own home by inviting relatives and neighbors. Salamatan is usually held on Friday afternoon, i.e, after the men returned from the mosque. Kokoleh porridge dishes are also available, but during a ceremony this salamatan, kokoleh only as a requirement. The food was served at the ceremony salamatan is rice and side dishes. Prayer is prayer that is read salamat and starting reinforcements. The attendees consisted of neighbors, especially the men plus the Ulema as master of ceremonies salamatan.

Then when the rice has flowered (named maurai), in Dalam Pagar Village is no informant who said that farmers will surround the field while splashing oil mixed with jasmine (minyak likat boboreh). Se the return of the fields, in the farmhouse held salamatan attended by family only to serve bubur ba-ayak. Bubur ba-ayak made from rice flour and shaped like small grains, which are usually associated with full grain. In addition there is also a gold soak, and gold immersion water is distributed to the fields, an action intended to order the harvest abundant.

\section{B. Mangatam (Harvest)}

Before the rice dikatam (harvested) in a gang, usually performed the ceremony bamula or known as batampung bargaining. Time for bamulalbatampung tawar accurately determined, as well as begin to grow rice. If bamula mangatam ceremony will take place on Sunday, then the activity has started since Saturday afternoon. The afternoon ritual aims to gather the spirit of rice to be harvested the next day. For the purposes of ritual usually farmers bring upat (torch made of palm leaves that have dried flowers, in which there is a part of a coconut shell and weeds that have been dried). Ritual begins with the position of farmers who are in the middle of rice fields and utter mamangan (spell) in a puff of smoke upat. Fill mamangan/mantra spoken among others:

"Assalamu'alaikum hai dangsanakku Nur hayatullah, lakasi kasini bakumpulan sabarataan nang di paksina, daksina, masyrik lawan di magrib, aku handak manyambut ikam dangsanakku lawan ku andakakan ikam barataan di wadah nang paling baik". Meaning: Assalamu'alaikum hai my brother Nur hayatullah (name of the rice soul), let here gather all of them, in the north, south, east and west, I want to welcome you and I place you in the best place.

After mamangan/spell spoken, then upat placed on the rice field. Implementation of this ritual with oil splashed around the field while (minyak likat boboreh) into rice plants. When batampung tawar blessings spoken out loud, but there are also farmers who only mentions "kur sumangat". Meanwhile whenever arriving at each corner of the fields, a clump of rice and then tied up as sidat bond, so that later there will be four ties sidat bond of rice. Sidat bond is simple binding way that if one end of the rope is pulled, the bonds will be detached. At the time of making the sidat bond on rice clump recited prayers " 'Alimullah,' Alimul Muhammad, 'Alimul Invisibility". The intention is that urang halus passage (supernatural beings) do not interfere with the fields.

Next day early in the morning do banih laki bini reception preparation to be harvested at a time bamula mangatam (start harvesting). At that time, farmers will oversee the rice stalks were moving as if asking allegedly harvested, two stalks of rice crouching and facing each other (this is called a rice male chant). These two rice stalks will be the first to be harvested. When going to harvest rice, it must first be read Shahada and Ayat Kursi (Ayat Allahula).

Dishes available at the time of rice harvest process (mangatam) generally lapat or kokoleh, the dish was placed in a hut (hut that was in the fields). Ma-lapat/make lapat associated with mandapat / received while kokoleh associated with bapakoleh (get results). Farmers working in nearby fields are invited to attend the prayers and enjoy the meal.

\section{Imbah Katam (After the Harvest)}

After a few days mangatam, some of the crops dried and pulverized to be used as a rice directly. The rice that has been cooked will be holding a ritual dish salamatan "mahanyari banih" (try the newly harvested rice) with the reading of prayers as a form of gratitude to Allah SWT. This event is usually attended only family members or invite some neighbors.

In the post-harvest ritual is also known as the capacity of the bargain. There are also some farmers who said that after the completion manampung selling to the rice granary (Kindai) to serve nasi lakatan (glutinous rice) and hinti (head grated cooked with brown sugar), prayer is a prayer that is 
read when bahalarat ( prayer as an expression of gratitude). Therefore, this ritual is often called the ritual bahalarat banih or salamatan Pisit banih or tuntung katam ceremony. On the occasion of this bahalarat banih usually farmers are obliged to pay zakat paddy. In accordance with Islamic law, usually the farmer will issue zakat paddy for $10 \%$ of all the results obtained.

In addition bahalarat banih ritual, Banjar tribe farmers also recognize the term ritual mamalas Handil. Handil mamalas ritual performed as an expression of gratitude to God who has bestowed fortune is also intended to invoke the protection of that agricultural land where they tried to always be planted and can provide fruitful. By carrying out this ritual mamalas handil, farmers hope to save farmland of pests or another disaster that resulted in the failure of the harvest. Because the word mamalas means clearing the ground of the various possible natural disasters and plagues.

Mamalas handil operational time is after harvest. Implemented after harvest because this activity requires a cost, so that from the harvest can be set aside for the cost of organizing the ritual. Usually mamalas handil ritual will conclude with a prayer safely and eat together. To eat together, the dishes provided are animals such as cow, buffalo, goat or just enough chicken only. This type of animal victim depends on the ability of farmers. As proof that they plead for the safety of the farms they are working on is the blood of the slaughtered animals slaughtered into the river. In the past, the head of a caged animal was planted on the farm, but now it is no longer.

\section{DISCUSSION}

Before Islam entered and developed, Indonesia already has a cultural style that is influenced by Hinduism and Buddhism. All that can not be separated from previous influences, namely the culture of the ancestors (animism and dynamism), and Hindu Buddhism that developed earlier than Islam. With the entry of Islam, Indonesia again experienced the acculturation process that gave birth to a new culture that is Indonesian Islamic culture. The entry of Islam does not mean the culture of the ancestors just disappeared. The form of culture as a result of the acculturation process (Islam and ancestral culture), is not only material / material but also concerns the behavior of Indonesian society. In line with this, Smith [3] explains that although the beliefs of society change, some religious rituals are preserved in order to reinforce their social unity. This is in line with the opinion of the [13] rituals reduce individual-level conflicts inherent in group living, a Necessary condition for coalitional Achieving goals. Precisely religious ritual is done not just to worship and closer to God Almighty, but also done to fulfill social obligation.

Rituals associated with the activities of the region bahuma South Kalimantan, especially farmers Banjar tribe can be seen in two types of activities mentioned aruh and salamatan. Aruh ceremony held as mandatory and binding hereditary, while salamatan held in accordance with the applicable purposes. Aruh aims to raise the public for certain ceremonies or holding gawi (work together) with aspects of religion, including entertainment can be contained in it but the pressure is stronger in terms of its religious. Salamatan emerged after Islam entered in public life Banjar tribe. Salamatan to do with the presence of three or four people, the pressure readings that are being said salamat prayers to God Almighty to be blessed with safety, or welfare.

Ritual activities in bahuma intended to harvest abundant and avoid crop failure resulting in losses for farmers. The purpose of the rituals of the Banjar tribe farmers has in common with rituals performed by Magindanawn farmers in the Philippines. Reference [14] describes a ritual performed Magindanawn farmers in the Philippines aims to communicate with uyag-uyag (soul that gives fortune) in order to harvest abundant. Similarly, research conducted by [15][16][17] shows the same thing that rituals done by farmers have a goal to harvest crops and avoid harvest failure.

Rituality is the most important bond in religious life in society. The beliefs of society and its practice are apparent in the rituals held by the community itself. The rituals that are held can even encourage people to do and obey the values and social arrangements that have been mutually agreed upon. In other words, rituals provide deep motivation and values for someone who believes in and practices them.

Implementation of the ritual is closely related to the symbols used. So it can be said that it is impossible to understand the form, nature, and meaning of rituals without knowing deeply the ritual symbols used. According to [20] a symbol is an object or event that points to something. Symbols are part of a ritual that holds something of meaning or behavior in a typical ritual ceremony.

Ritual activities by farmers Banjarese bahuma full of symbols and meanings contained therein. Symbols in the bahuma ritual, Banjar tribe farmers group among other hole (umang) to plant rice seeds made odd (starting with 3, 7 or 9 holes). The reason for the selection of odd numbers by Banjar tribe farmers who mostly embraced Islam because many privileges features of the numbers contained in the Qur'an. With the start of the process of planting seeds of rice on the odd holes, Banjar tribe farmers hope that the process bahuma they do bring blessings from Allah SWT. Other symbols in ritual bahuma is presented Kokoleh, lapat, and bubur ba-ayak. Kokoleh dish made from rice flour and coconut milk mixture made lumpy like porridge, where dishes Kokoleh by farmers Banjarese associated with the term bapakoleh (get results). Banjar tribe farmers expect to kokoleh with their dish of rice planted the seeds will give good results. Lapat dish made of rice wrapped in banana leaves and shaped rectangles, then the package tied with a rope so that the rice is in the leaves do not come out when cooked. Ma-lapat term is defined by the gain, so Banjar tribe farmers expects to receive the results overflow/double at time of harvest. In addition Kokoleh dish and lapat, in bahuma ritual of Banjar tribe farmers also found porridge dish (bubur ba-ayak). Bubur ba-ayak made from rice flour and shaped like small grains. With pulp served bubur baayak, Banjar tribe farmers hoped that rice planted seed will produce a full grain. Other symbols in ritual bahuma is where upat and sidat bonding. Upat and sidat bond created with the 
aim of making batas gaib (magical limits) in the fields to be harvested. With the magical limits supposedly urang halus (supernatural beings) will not see the paddy ready for harvest so that urang halus (supernatural beings) does not interfere with the fields.

Disclosure of the meaning behind the symbols used in the ritual bahuma Banjar tribe farmers in line with the interactionist symbolic theory by Blumer [18]. The basic assumption of interactionist symbolic theory that man acts upon something on the basis of the meaning of that symbolic value. The meaning of the symbols is the result of social interaction in society. It means that human interaction is bridged by the use of symbols, by interpretation, and by the certainty of the meaning of the actions of others. Turner [15] explains that through the analysis of ritual symbols will help explain correctly the value that exists in society and will dispel doubts about the truth of an explanation. In analyzing the meaning of the symbols on the activities of ritual, used theory proposed interpretation Turner [15] as follows: 1) exegetical meaning is the meaning derived from local residents about the informant observed ritual behavior. In this case, it is necessary to distinguish between the information provided by the informant laymen and experts, between esoteric and exoteric interpretation. A researcher should know for sure whether the explanation given by the informant was truly representative and or just the views of unique individuals, 2) Operational obtained meaning that the meaning is not limited to the words of the informant, but of the action taken in the ritual. In this case should be directed to the information level, the problem of social dynamics, 3) Potitional meaning is the meaning obtained through the interpretation of the symbol in conjunction with any other symbol of the totality. This level of meaning is directly linked to the owner of the ritual symbol. In other words, the meaning of a ritual symbol must be interpreted into the context of the symbol and its owner.

\section{CONCLUSION}

Ritual activities undertaken farmers bahuma Banjarese nuances of Islam, since the majority of farmers Banjar tribe embraced Islam. The symbols contained in bahuma ritual full of meaning/significance. By performing the ritual in bahuma activities, farmers Banjarese expect abundant harvests and avoid crop failure resulting in losses for farmers. Ritual in bahuma contained in the following activities: manaradak (seed), batanam (growing rice), mangatam (harvest), and imbah katam (after the harvest).

\section{REFERENCES}

[1] P. Leevang, Come to the Land of Sabrang: Transmigration in Indonesia. Jakarta: Popular Gramedia Library, 2003.

[2] E. W. Rothenbuhler, Ritual Communication: From Everyday Conversation to Mediated Ceremony . Thousand Oaks. SAGE Publications, 1998.

[3] N. Couldry, Media Rituals; Beyond Functionalism., In Media Anthropology. Editor: Eric W. Rothenbuhler and Mihai Coman. Thousand Oaks: SAGE Publications, 2005.

[4] F. Ngare, "Studies Cultural Communication On Ritual Ceremony Congko Lokap and Penti As Media Communication in Regional Tourism Development Manggarai East Nusa Tenggara Province" . Journal of Communication Vol 1 No. 1 April 2014, 2014

[5] F. Bowie, Ritual Theory, Ritual Rites of Passage and Violence. In The Anthropology of Religion, 2000.

[6] S. Endahwati, "Jolenan Traditional Ceremony in Kaligesing Sub-district, Purworejo District”. BASASTRA Jurnal Penelitan Bahasa, Indonesian Literature and Teaching. Vol 1 No. 1, April 2012

[7] R. Rappaport, Ritual and Religion in The Making of Humanity . Cambridge, England: Cambridge University Press, 1999.

[8] Koentjaraningrat, Introduction to Anthropology. Jakarta: PT. Rineka Cipta, 2002

[9] S. Ideham, Urang Banjar and their Cultural. Yogyakarta: Publisher Ombak, 2015.

[10] J. W. Carey, Communication as Culture: Essays on Media and Society. New York: Routledge, 1992.

[11] C. Bell, Ritual Theory, Ritual Practice. Published by Oxford University Press, Inc, 2009.

[12] N. B. Miles, and A. M. Huberman, Qualitative Data Analysis. Sourcebook of New Methods. Tjetjep Rohendi Rohidi, translators Jakarta UI Press. Translation From: Qualitative Data Analysis, 2014.

[13] R. E. Watson-Jones, "The Social Functions of Group Rituals. Association for Psychological Science", Vol 25 (1), pp 42-46. Sagepub.com/journals. Doi: 10.1177 / $0963721415618486,2016$.

[14] S. M. Mantikayan, "Traditional Rice Farming Ritual Practice of The Magindanawn in Southern Philippines", American Journal of Agriculture and Forestry. Published online November 5, 2015. doi: 10.11648 / j.ajaf.s.2015030601.14 ISSN: 2330-8583 (Print); ISSN: 2330-8591 (Online), 2015.

[15] MB. Khattri, Agriculture and Ritual Landscape: A Case Study from The Magars of Argal, Baglung District, Nepal, retrieved from http://www.dspace.cam.ac.uk/handle/1810/229121, 2003.

[16] E. J. Jossie, and MA. Sudhir, "Mundiyankalasam: An Eco-Cultural Ritual of Ancient Farming Community”. Study Tribes Tribal, 10 (1): pp 7-12, 2012.

[17] A. Ramkumar, "Rice, Risk and Ritual: What Agriculture and Religion Tell Us about the State-Minority Relations among the Khmu of Northern Laos" . The Journal for Undergraduate Ethnography Vol 5, Issue 2, 2015.

[18] D. Ahmadi, "Symbolic Interaction: An Introduction". Journal of Mediator, Vol 9, No 2, December 2008. 